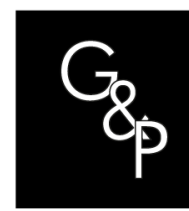

\title{
Study of the rate of generation of waste from construction in new works in the city of Ribeirao Preto-SP
}

\author{
Estudo da taxa de geração de resíduos da construção civil em \\ obras novas na cidade de Ribeirão Preto-SP
}

\author{
Luiz Paulo da Silva ${ }^{1}$ (1), José da Costa Marques Neto ${ }^{1}$ (1) \\ ${ }^{1}$ Universidade Federal de São Carlos - UFSCar, Programa de Pós-graduação em Estruturas e Construção Civil - \\ PPGECiv, São Carlos, SP, Brasil. E-mail: silvaluizpaulo1@gmail.com; joseneto@ufscar.br
}

How to cite: Silva, L. P., \& Marques Neto, J. C. (2020). Study of the rate of generation of waste from construction in new works in the city of Ribeirao Preto-SP. Gestão \& Produção, 27(4), e5236.

https://doi.org/10.1590/0104-530X5236-20

\begin{abstract}
In the construction industry, many waste products are produced most part of the time, because they do not have a correct end, end up causing strong impacts on the environment. To this end, CONAMA Resolution No. 307/2002 and its amendments thereafter determine the guidelines for the management of civil construction waste appropriately. In this context, this article aims, through a quantitative study, to identify the situation of civil construction waste, called here as RCD, in the city of Ribeirao Preto, determining the amount of waste generated through two parameters; licensed areas and volume disposed of at authorized locations, from a generation rate of $183.28 \mathrm{~kg} / \mathrm{m}^{2}$, generating $1,112.35 \mathrm{t} /$ day and $561.98 \mathrm{t} /$ day respectively. The work sought to relate the values and obtained a per person generation of $1.24 \mathrm{~kg} / \mathrm{inhab} \times$ day. Thus, the article identified and measured the generation of construction waste in the city of Ribeirao Preto-SP, providing subsidies and information for comparisons with existing bibliography.
\end{abstract}

Keywords: Conama; Development; Management; Waste.

Resumo: Atualmente com o crescimento econômico e o desenvolvimento das cidades, fica em destaque o que fazer com os resíduos produzidos pela sociedade. Na atividade da construção civil, são produzidos diversos resíduos, que na maioria das vezes por não terem um final correto, acabam provocando fortes impactos ao meio ambiente. Para isso, a resolução CONAMA $n^{\circ}$ $307 / 2002$ e posteriormente suas alterações, determinam as diretrizes para a gestão dos resíduos de construção civil de forma adequada. Nesse contexto, o presente artigo tem como objetivo principal, por meio de um estudo quantitativo, identificar a situação dos RCC na cidade de Ribeirão Preto, determinando a quantidade de resíduos gerados, através de dois parâmetros; áreas licenciadas e volume descartado em locais autorizados, a partir de uma taxa de geração encontrado no valor de $183,28 \mathrm{~kg} / \mathrm{m}^{2}$ obtendo uma geração de $1.112,35 \mathrm{t} / \mathrm{dia}$ e $561,98 \mathrm{t} / \mathrm{dia}$ respectivamente. $\mathrm{O}$ trabalho buscou relacionar os valores e obteve uma geração per capita de $1,24 \mathrm{~kg} / \mathrm{hab} \times$ dia. Com isso, o artigo identificou e mesurou a geração de resíduos da construção civil no município de Ribeirão Preto-SP, fornecendo subsídios e informações para as tomadas de decisões pelo executivo local.

Palavras-chave: Conama; Desenvolvimento; Gestão; Resíduos.

Received Dec. 10, 2018 - Accepted July 2, 2019

Financial support: None.

This is an Open Access article distributed under the terms of the Creative Commons Attribution License, which permits

unrestricted use, distribution, and reproduction in any medium, provided the original work is properly cited. 


\section{Introduction}

The concept of construction waste generation rate is based on waste generation, based on two parameters: areas licensed for construction of new works and generation in authorized disposal sites.

In Brazil, the construction sector has an important highlight in the process of economic growth, favoring development and reducing unemployment rates. However, this advance generates construction residues, which are often disposed of in irregular places. Pinto (1999) estimates that about $70 \%$ of solid waste generated in urban areas comes from construction.

Li \& Zhang (2013) state that the "RCD", construction waste consists around $10 \%$ to $30 \%$ of the total solid waste generated by any society.

In countries such as India, where quick urbanization occurs, due to a projected investment of US $\$ 1$ trillion during the years 2012 to 2017 , in infrastructure, it is estimated the generation of large amounts of construction waste, a fact that this can lead to major problems if the country does not have adequate treatment legislation (Make in India, 2016).

The National Policy on Solid Waste, which sets forth the principles, objectives, management guidelines and responsibilities of the generating agents, from 2010 onwards, begins to awaken in the Brazilian Municipalities a new view of the environmental management of solid waste generated, with this, there is the need for public and private initiative in order to solve and minimize the impacts generated by solid waste disposed of in inappropriate places.

With that, Lu et al. (2017) points to the need for a reliable construction waste generation estimate to be adopted in the development of a management system for a specific region.

In determining RCD generation rates, the work provides tools and subsidies for process companies such as construction companies, transporters, and final disposal companies to understand the material and thus propose better handling and logistics for the process.

Through the analysis and determination of the rate of generation of construction waste in the city of Ribeirao Preto-SP, the study methodology sought to provide the generation of construction waste by two parameters: licensed areas and disposal in authorized locations. It also sought to provide per person generation of the municipality.

Therefore, estimating the rate of waste generated from the construction of a city is a major factor to know and diagnose the situation of RCD in the region under study. Thus allowing indicate the guidelines to be adopted by the municipal executive for the implementation of integrated management plans.

In this context, this work aims to calculate the estimated rate of generation of construction waste in the city of Ribeirao Preto-SP and from then, to determine the annual, monthly and daily generation of RCD through two parameters (Survey of areas licensed for construction and disposal in authorized locations) and determine the probable per person a generation of the city of Ribeirao Preto-SP.

\section{Theoretical reference}

This study presents a survey of the theoretical framework based on the existing and well-known literature, addressing the issues of civil construction production in the 
construction sector, environmental impacts and the situation of civil construction in Ribeirao Preto-SP.

\subsection{RCD production in the construction sector}

In recent years, with the development of cities, as well as population growth, the increase in the generation of construction waste has been predominant. In this context, several studies were carried out with the purpose of quantifying the generated waste and identifying the stages of the work most conducive to waste generation.

For Buselli (2012), following the construction industry presents a huge variety of materials used, from combustible materials to aggregates obtained from mineral extraction processes, this fact explains the huge volumes of construction waste generated in the world.

According to Villoria Sáez et al. (2012), the construction industry generates more than 890 million tons of waste per year in EU countries.

For Mália et al. (2013), the number of RCDs produced can represent around $25 \%$ to $30 \%$ of all waste produced worldwide, highlighting Denmark, which is the most developed country in the European Union.

For Mann et al. (2014), waste generation rates from country to country may vary, depending on construction methods, management systems and public policies, but there is no relationship between the country being less developed and generating a smaller amount of construction waste.

According to Dias (2013), it is necessary to act from the conception to the implementation phase of an enterprise to try to avoid or reduce the generation of waste. Also very important is to know waste generation indexes to define management strategies.

According to Bidone (2001), the development of the construction sector is related to a population increase, technological development and raising the standard of living of the population. As a result, there was a significant increase in energy and raw material consumption, causing several environmental impacts due to the excess of waste generated.

For Pinto \& González (2005), the construction activity is responsible for generating the predominant portion of the entire mass of urban solid waste produced in the cities.

It must be considered that the population growth of cities and the high housing deficit pressure the construction sector to produce more and thereby generate more waste (Carneiro et al., 2001).

Formoso et al. (1998), states that the generation of RCD in the construction phase occurs due to losses in the construction processes, highlighting the construction, maintenance and demolition phases.

According to John (2001), the intensity of the construction activity, the construction processes and the generated waste rates are major factors for the value of the RCD generation rate.

According to John (2000), at the international level, they point out that in several countries the estimated generation varies between 130 and $3000 \mathrm{~kg} / \mathrm{inhab} \times$ year. Table 1 represents the generation of construction waste in several countries around the world. 
Table 1. Estimation of RCD Generation Worldwide.

\begin{tabular}{ccc}
\hline Place & Generation $\mathbf{( k g / \mathbf { m } ^ { 2 } )}$ & Source \\
\hline Developed countries & $<100$ & Monteiro et al. (2001) \\
\hline Brazil & 300 & Monteiro et al. (2001) \\
Spain & 107.6 & Solís-Guzman et al. (2009) \\
\hline Sao Paulo & 150 & Pinto (1999) \\
\hline Sao Paulo & 49.58 & Andrade et al. (2001) \\
\hline Sao Paulo & $104-115$ & Careli (2008) \\
\hline Recife - PE & $69-86$ & Carneiro (2005)
\end{tabular}

Source: Costa (2012), adapted by the author.

Córdoba (2010) states that the study of RCD generation has several studies in Brazilian cities involving the isolated municipality or the municipalities of a watershed.

In this context, Marques Neto (2009) conducted a study involving the municipalities of the Turvo Grande watershed (UGRHI-15), pointing out the generation of RCD in 64 municipalities. Table 2 shows the results of 8 municipalities:

Table 2. Estimation of RCD generation in some Brazilian municipalities.

\begin{tabular}{|c|c|c|c|c|c|}
\hline Cities & $\begin{array}{l}\text { Population } \\
\text { (Thousand) }\end{array}$ & $\begin{array}{l}\text { Generating } \\
\text { Mass (t/day) }\end{array}$ & $\begin{array}{c}\text { Generated } \\
\text { Volume } \\
\text { (m³/day) }\end{array}$ & $\begin{array}{l}\text { Per person } \\
\text { generation } \\
\text { (L/inhab.day) }\end{array}$ & Source \\
\hline Catanduva - SP & 112 & 150 & 125 & 1.11 & $\begin{array}{c}\text { Marques } \\
\text { Neto (2009) }\end{array}$ \\
\hline Fernandopolis - SP & 65 & 82 & 68 & 1.05 & $\begin{array}{c}\text { Marques } \\
\text { Neto (2009) }\end{array}$ \\
\hline Macedonia - SP & 4 & 6 & 5 & 1.25 & $\begin{array}{c}\text { Marques } \\
\text { Neto (2009) }\end{array}$ \\
\hline Mirassol - SP & 53 & 77 & 64 & 1.21 & $\begin{array}{c}\text { Marques } \\
\text { Neto (2009) }\end{array}$ \\
\hline Olimpia - SP & 50 & 76 & 63 & 1.26 & $\begin{array}{c}\text { Marques } \\
\text { Neto (2009) }\end{array}$ \\
\hline Paulo de Faria - SP & 9 & 17 & 14 & 1.56 & $\begin{array}{c}\text { Marques } \\
\text { Neto (2009) }\end{array}$ \\
\hline Sao Carlos - SP & 197 & 381 & 635 & 3.22 & $\begin{array}{c}\text { Marques } \\
\text { Neto (2003) }\end{array}$ \\
\hline $\begin{array}{l}\text { Sao Jose do Rio } \\
\text { Preto - SP }\end{array}$ & 413 & 1267 & 1056 & 2.56 & $\begin{array}{c}\text { Marques } \\
\text { Neto (2009) }\end{array}$ \\
\hline
\end{tabular}

Source: Marques Neto $(2003,2009)$ adapted by the author.

According to Pinto (1999), it is of fundamental importance for builders to identify and know the loss-related indices, seeking to invest in improvements to obtain better market competitiveness.

Andrade et al. (2001) estimated the waste per service unit. This study considered the RCD mass per square meter, through indicators that relate the quality of service performed with the floor area of the building, and then multiplying the rubble values by the square meter of floor per RCD mass, obtained the value of $49.58 \mathrm{~kg} / \mathrm{m}^{2}$.

Castro (2003) conducted a study with the same parameters to estimate the total generation of RCD in the city of Santos-SP. The research was based on establishing a quantitative analysis of building permits, the amount of buckets used in the city and the 
amount of rubbish collected by the city during public cleaning operation. This study obtained a rubble production of $11,295.98 \mathrm{t} /$ month.

In the United States, according to Freeman (1994), data on RCD production are inaccurate, as it is based on studies that may be outdated, with a generation of 31.5 million tons of RCD annually.

According to ABRELPE (2011), 106,549 tons of construction waste are produced daily. However, the collection of RCD often does not cover all the waste generated, as its collection and disposal is the responsibility of its generators. Table 3 below presents the waste production in different Brazilian regions:

Table 3. Probable RCD generation by regions.

\begin{tabular}{cccccccc}
\hline & 2010 & & & \multicolumn{3}{c}{$\mathbf{2 0 1 1}$} \\
\cline { 6 - 7 } \cline { 6 - 7 } Region & $\begin{array}{c}\text { RCD } \\
\text { (t/day) }\end{array}$ & $\begin{array}{c}\text { Index KG } \\
\text { (inhab/day) }\end{array}$ & $\begin{array}{c}\text { Urban Population } \\
\text { (inhab) }\end{array}$ & $\begin{array}{c}\text { RCD } \\
\text { (t/day) }\end{array}$ & $\begin{array}{c}\text { Index Kg } \\
\text { (inhab/day) }\end{array}$ \\
\hline North & 3,514 & 0.301 & & $11,833,104$ & 3,903 & 0.330 \\
\hline Northeast & 17,995 & 0.464 & & $39,154,163$ & 19,643 & 0.502 \\
\hline Midwest & 11,525 & 0.923 & & $12,655,100$ & 12,231 & 0.966 \\
\hline Southeast & 51,582 & 0.691 & & $75,252,119$ & 55,817 & 0.742 \\
\hline South & 14,738 & 0.634 & & $23,424,082$ & 14,955 & 0.638 \\
\hline Brazil & 99,354 & 0.618 & & $162,318,568$ & 106,549 & 0.656
\end{tabular}

Source: ABRELPE (2011).

Costa (2012) conducted a study in the city of João Pessoa-PB, verifying the generation of RCD in 35 works. However, it obtained the RCD generation rate indicator of only 22 works, according to Table 4 . The generation rate was obtained with the relation between the RCD mass and the built area. To find the average of these rates, weighted average were executed. Through the obtained data analyzes were performed to verify the behavior of the generation of RCD in the several stages of the works and reaching the end with the generation rate in $\mathrm{kg} / \mathrm{m}^{2}$.

Table 4. List of completed works and RCD generation rate.

\begin{tabular}{|c|c|c|c|c|c|c|}
\hline Work & User & $\begin{array}{c}\text { Constructed } \\
\text { Area }\left(\mathrm{m}^{2}\right)\end{array}$ & $\begin{array}{c}\text { RCD } \\
\text { Volume }\left(\mathrm{m}^{3}\right)\end{array}$ & $\begin{array}{c}\text { RCD } \\
\text { Discarded } \\
\text { Mass (kg) }\end{array}$ & $\begin{array}{c}\text { RCD } \\
\text { Generation } \\
\text { Rate }\left(\mathrm{kg} / \mathrm{m}^{2}\right)\end{array}$ & $\begin{array}{c}\text { RCD Class A } \\
\text { Generation } \\
\text { Rate }\left(\mathrm{kg} / \mathrm{m}^{2}\right)\end{array}$ \\
\hline 1 & Private & 985.50 & 97.0 & $99,425.00$ & 100.89 & 93.83 \\
\hline 3 & Private & $43,858.80$ & $3,854.5$ & $3,950,862.50$ & 90.08 & 83.78 \\
\hline 4 & Private & $16,976.51$ & $1,515.5$ & $1,553,387.50$ & 91.50 & 85.10 \\
\hline 5 & Private & $1,250.00$ & 120.0 & $123,000.00$ & 98.40 & 91.51 \\
\hline 6 & Private & 950.00 & 100.0 & $102,500.00$ & 107.89 & 100.34 \\
\hline 7 & Private & $1,780.00$ & 140.0 & $143,500.00$ & 80.62 & 74.98 \\
\hline 8 & Private & $1,949.00$ & 180.0 & $184,500.00$ & 94.66 & 88.03 \\
\hline 9 & Private & $1,194.50$ & 144.0 & $147,600.00$ & 123.57 & 114.92 \\
\hline 10 & Private & 998.00 & 105.0 & $107,625.00$ & 107.84 & 100.29 \\
\hline 12 & Private & 70.00 & 10.0 & $10,250.00$ & 146.43 & 136.18 \\
\hline 13 & Private & 95.00 & 10.5 & $10,762.50$ & 113.29 & 105.36 \\
\hline 14 & Private & 150.00 & 11.0 & $11,275.00$ & 75.17 & 69.91 \\
\hline 16 & Public & $2,299.02$ & 203.1 & $208,177.50$ & 90.55 & 84.21 \\
\hline
\end{tabular}


Table 4. Continued...

\begin{tabular}{|c|c|c|c|c|c|c|}
\hline Work & User & $\begin{array}{l}\text { Constructed } \\
\text { Area }\left(\mathrm{m}^{2}\right)\end{array}$ & $\begin{array}{c}\text { RCD } \\
\text { Volume }\left(\mathrm{m}^{3}\right)\end{array}$ & $\begin{array}{c}\text { RCD } \\
\text { Discarded } \\
\text { Mass (kg) }\end{array}$ & $\begin{array}{c}\text { RCD } \\
\text { Generation } \\
\text { Rate }\left(\mathrm{kg} / \mathrm{m}^{2}\right)\end{array}$ & $\begin{array}{c}\text { RCD Class A } \\
\text { Generation } \\
\text { Rate }\left(\mathrm{kg} / \mathrm{m}^{2}\right)\end{array}$ \\
\hline 17 & Public & 997.64 & 165.5 & $169,586.25$ & 169.99 & 158.09 \\
\hline 19 & Public & 840.00 & 72.0 & $73,800.00$ & 87.86 & 81.71 \\
\hline 20 & Public & 445.56 & 48.5 & $49,712.50$ & 111.57 & 103.76 \\
\hline 21 & Public & 232.45 & 36.0 & $36,900.00$ & 158.74 & 147.63 \\
\hline 22 & Public & 394.30 & 38.5 & $39,462.50$ & 100.08 & 93.08 \\
\hline 24 & Public & 754.93 & 76.5 & $78,412.50$ & 103.87 & 96.60 \\
\hline 29 & Public & $4,997.00$ & 508.3 & $521,007.50$ & 104.26 & 96.96 \\
\hline 34 & Public & 455.40 & 39.5 & $40,487.50$ & 88.91 & 82.69 \\
\hline 35 & Public & $1,031.80$ & 100.4 & $102,910.00$ & 99.74 & 92.76 \\
\hline
\end{tabular}

Source: Costa (2012).

\subsection{Environmental impacts of construction waste}

Construction is a sector of the economy that grows considerably each year. This fact, associated with technological development, generates more and more waste from its construction process, which, when disposed of in inappropriate places, generates major impacts on the environment.

For Resolution $\mathrm{n}^{\circ} .001$ of the National Environment Council of September 23, 1986 (CONAMA), defines the expression, environmental impact as:

Any change in the physical, chemical and biological properties of the environment caused by any form of matter or energy resulting from human activities that directly or indirectly affect the health, safety and welfare of the population, social and economic activities; the biota; the aesthetic and sanitary conditions of the environment; and the quality of environmental resources (Brasil, 1986).

According to Bidone (2001), construction and demolition wastes generate environmental impacts related to the increase of energy and raw material consumption for their construction process, generating significant amounts of RCD.

According to Marques Neto (2009), the impacts generated by RCD production in cities can reach three dimensions:

- Economic;

- Social;

- Environmental.

According to Cardoso (2010), the environmental impacts that occur as a result of civil construction can be divided into two parameters: the consumption of natural resources and the generation of civil construction waste.

Regarding the consumption of natural resources, environmental impacts are related to the extraction and consumption of non-renewable materials that are found in the environment, such as stone, sand and wood. Regarding the environmental impacts related to the generation of $R C D$, they are those generated from the construction activity, involving the losses and waste of materials.

According to Lúcio (2013), for each material used in a work, there is a production chain, which plays an important role in the macro-sector of the economy involving companies linked to construction. Thus, each production chain can generate serious environmental impacts for the production of its products. 
Tozzi (2006) states that the generation of RCD can generate environmental impacts in two stages: generation and final disposal. The author adds that in construction sites pollution occurs due to poor waste management.

For Ângulo \& John (2004), the inefficiency of specific policies for construction waste has been causing strong environmental impacts, such as the emergence of clandestine landfills and its exhaustion. Being able to see the landfills of RCD, through a negative optics, that is, as an environmental impact.

For Dias (2004), the construction activity is composed of a network of activities that include extraction, mining, consumption and transformation activities. Thus becoming a major consumer of an economy's natural resources.

According to Abreu (2016), the main environmental impacts due to mining are the change in air quality, fauna displacement, visual impact, vector proliferation and alteration in groundwater flow regime.

\subsection{Situation of RCD in Ribeirao Preto - SP}

In Ribeirao Preto, based on work done by SindusCon (Union of the Construction Industry) and AEAARP (Association of Engineering, Architecture and Agronomy of Ribeirao Preto), and later with the implementation of the Construction Waste Management Program by the City hall, were established the bases and guidelines for the implementation of an Integrated Plan for the Construction Waste Management. In 2008, the support points for the disposal of waste and small volumes, called recitulhos, were implemented (Mello \& Monteiro, 2007).

AEAARP's work began with the organization of the discussion table on the topic of Construction Waste management in Ribeirao Preto. The debate under the organization of the "Permanent Debate Forum" was coordinated by the engineer Ericson Dias Mello, then Coordinator of the Debate Forum, and was attended by professionals from the area, such as Engineer Wilson Luiz Laguna, at the time president of AEAARP, and also Engineer José Batista Ferreira, President of SindusCon, for discussion and suggestions on the subject. After the discussion table, a Special Committee for Studies and Research was created by AEAARP to organize and systematize the subjects of Construction Waste. This commission was coordinated by Civil Engineer José Alfredo Pedreschi Monteiro.

The commission's work began with a technical visit to the city of Sao Jose do Rio Preto, where a construction waste management plan was successfully implemented, and it work started in 2002 and implemented in 2005. The delegation visited the Points City Support Center, recitulhos, places for the reception and sorting of small volumes, under the responsibility of the public power, functioning as a central where collectors organized in cooperatives collect and lead the material to the Support Points. The material is sorted and forwarded to recycling plants, and the sale guarantees to collectors compensation and greater social inclusion. The visit also passed for the Waste Processing Plant, where a precast concrete factory operates.

The visit to the city of Sao Jose do Rio Preto served as an example for its implementation in the city of Ribeirao Preto, and after the visit, a survey was conducted by Dr. Mariel Silvestre, member of the OAB/SP Environment Commission and member of the forum committee, which made the comparative analysis of the legislation of Sao Jose do Rio Preto and Ribeirao Preto.

After this study, were created in Ribeirao Preto the recitulhos that as in the city of Sao Jose do Rio Preto, acting as support points. Licensed and authorized points for 
the disposal and sorting of construction waste, among these support points, the participation of the private initiative, with the company ATT RECICLAX, created by the largest construction companies of the city in partnership and managed by Civil Engineer José Alfredo Pedreschi Monteiro, which currently receives the buckets from associated companies, individuals (Engineers, Architects and others) and the buckets for sorting and gives a proper end to the waste. The "recitulho" administered by Reciclax maintains some restrictions on material replacement, receiving only: 1) work waste, such as: earth, sand, gravel, crushed stone, bricks, plaster; 2) dry recyclable materials: paper, plastic, cardboard, metals, glass, wood; and 3) bulky materials: furniture and appliances.

At the time, Ribeirao Preto had a construction waste recycling plant, from City hall and some support points.

Over the years and a quick population growth, new areas for transshipment, sorting and recycling of construction waste generated in the city have been created.

Ribeirao Preto currently has five transshipments and sorting areas licensed to operate by the Ribeirao Preto City hall and CETESB. It also has six more construction waste recycling plants, including one from Ribeirao Preto City hall itself.

In the city of Ribeirao Preto, the Urban Cleaning Coordination was created, which aims to take care of urban cleaning, conserve public and private areas, take care of the collection and disposal of green waste, supervise the collection and disposal of construction waste.

Among the municipal social programs, the Urban Cleaning Coordination offers social buckets and the "cata treco" program.

The social buckets are distributed in the city of Ribeirao Preto in several places, aiming to act as a kind of ecopoints for the disposal of small construction waste. These buckets are collected weekly and taken to the Ribeirao Preto City hall's Construction Waste Recycling Plant.

\section{Methodology}

The present work was developed in Ribeirao Preto, SP, located $315 \mathrm{Km}$ from Sao Paulo, state capital, with 682,302 inhabitants, being classified as the eighth most populous municipality of Sao Paulo State, with a demographic density of 930, with 42 inhabitants per $\mathrm{Km}^{2}$ (IBGE, 2017). Firstly for the calculation of the construction waste generation rate, a selection of five works with different characteristics was carried out in the city of Ribeirao Preto, beginning and ending between 2013, 2014, 2015 and 2016, period determined for the study. Within the proposed methodology, the criteria used to determine the choice of the five works were:

- 5 works of different structural systems;

- 5 works executed and completed in the period from 2013 to 2016;

- 5 works of different size;

- 5 works of different standards;

Thus, the choice of these works, following the criteria established by the methodology, allows the sample to be studied as close as possible to reality, since the works carried out in Ribeirao Preto-SP, as well as in Brazil, can be performed. through different structural systems, generating different types of waste depending on the materials used, the size and standard of the work. In the present work, it was possible to analyze works in structural masonry, widely used in Brazil, in social programs of the 
Federal Government, as well as it was possible to include high standard residences, and works for commercial purposes.

The criterion of using different structural systems in the sample is justified by the fact that different materials are used in each building type. For example, when using the building system in structural masonry instead of the use in reinforced concrete, it is possible to reduce the amount of wood forms in execution, thereby reducing the generation of type B waste, where the wood fits.

From then on, the volumes of waste generated at each site were surveyed. To determine the RCD generation rate, the methodology proposed by Marques Neto (2003) was:

- Calculation of the sum of the constructed areas of the five works $\left(\mathrm{m}^{2}\right)$;

- Calculation of the RCD volume of the five works $\left(\mathrm{m}^{3}\right)$;

- Calculation of RCD Generation Rate $\left(\mathrm{kg} / \mathrm{m}^{2}\right)$

To calculate the RCD generation rate, Equations 1 and 2 were used:

$\mathrm{Me}=\mathrm{V} * \mathrm{M} . \mathrm{U}$.

$\operatorname{Tg}=\frac{\mathrm{Me}}{\mathrm{A}}$

At where:

Me = Rubble Mass;

$\mathrm{V}=$ Volume;

M.U. = Unit mass of rubble $=0.79 \mathrm{t} / \mathrm{m}^{3}$ (Obtained from the qualitative characterization of Ribeirao Preto, by the author);

$\mathrm{Tg}=\mathrm{RCD}$ Generation Rate;

$A=$ Sum of the areas of the five works under study.

Then, in the second part of the methodology, a technical visit was carried out at the City hall of Ribeirao Preto-SP in the urban planning sector, to survey the areas licensed for construction during the study period. This survey was related to the waste generation rate found in the first part of the methodology, providing the annual, monthly and daily generation of construction waste in the city of Ribeirao Preto-SP, quantitatively characterizing the RCD by the licensed areas parameter.

In the third part of the methodology, the quantitative characterization of RCD was performed by the parameter disposal in authorized places, where the adopted methodology describes a survey in the place where the rubble was received in a period of four months (September, October, November and December 2016), especially the company Reciclax, a licensed and authorized place for the reception, transshipments and sorting of construction waste. In Ribeirao Preto, this survey was carried out in 5 transshipments and sorting areas (ATT) that aims to receive the waste from construction, separate them by their typology and determine an appropriate destination for them. In the research these areas will be called ATT-A, ATT-B, ATT-C, ATT-D and ATT-E, in order to preserve the names and social reasons of private and public companies. The survey also includes the RCD recycling plants of the municipality, which in this research will be called POWER PLANT-A, POWER PLANT-B, POWER PLANT-C, POWER PLANT-D, POWER PLANT-E and POWER PLANT-F. 
Finally, in the fourth part of the methodology, the RCD generations found by the two studied parameters were related and thus providing the probable per person generation of the city of Ribeirao Preto, thus reaching the objectives established by the research.

\section{Results and discussions}

The RCD quantification methodology leads to the application of a method that provides the generation through two data parameters:

- Calculation of RCD generation through licensed areas;

- Calculation of the volume disposed of in municipal landfills.

According to Marques Neto (2003), the significant part in the production of RCD is destined to collecting companies and the other part, are used in the works themselves as landfill material, floor and wall filling.

For the calculation of the RCD generation rate, a survey of information and data related to the RCD generation was made in five works with different characteristics. Based on these data, the estimated RCD generation rate for the city of Ribeirao Preto was calculated, expressing the amount produced in $\mathrm{kg} / \mathrm{m}^{2}$. This case study is limited to calculating the RCD generation rate (first parameter presented), through five works by the construction company Pedreschi Monteiro Engenharia e Construção Ltda, which operates in the market since 1995, in the city of Ribeirao Preto - SP following buildings in structural masonry, high standard houses and subdivision.

The company is headed by Engineer José Alfredo Pedreschi Monteiro and coordinated by Engineer Marcelo Freire Monteiro, characterized by a family business with high solids in the Ribeirao Preto real estate market. The main economic activity of the company is the administration of works covering houses to closed lots.

The construction company Pedreschi Monteiro Engineering and Construction has a staff of four among which the author of this work, as a civil field engineer, makes it easy to obtain the data.

The buckets used in the work, had capacity for $3 \mathrm{~m}^{3}$ of construction waste and had their quantitative raised from the tax notes and WTC (Waste Transport Control) that were part of the documentation of the works under study. To determine the RCC generation rate, the value of $0.79 \mathrm{t} / \mathrm{m}^{3}$ was used for the unit mass of rubble. This value was found by the author by determining the composition of the construction waste made in three random buckets of the POWER PLANT-B. (Waste Plant of civil construction of the city of Ribeirao Preto, of the private sector), according to methodology of Marques Neto (2003). Comparing the value of unit mass of $0.79 \mathrm{t} / \mathrm{m}^{3}$ found by the author with the value of $0.6 \mathrm{t} / \mathrm{m}^{3}$ found by Marques Neto (2003), for the city of Sao Carlos-SP, we can say that the results found are compatible with the values practiced by the consecrated literature, having a small variation that can be justified by the fact of the characteristic difference in mass and volume of the compared municipalities.

The following are the five works studied and completed in the last 4 years, from figures 1, 2, 3, 4 and 5 respectively and their main characteristics (Chart 1): 
Chart 1. Studied works.

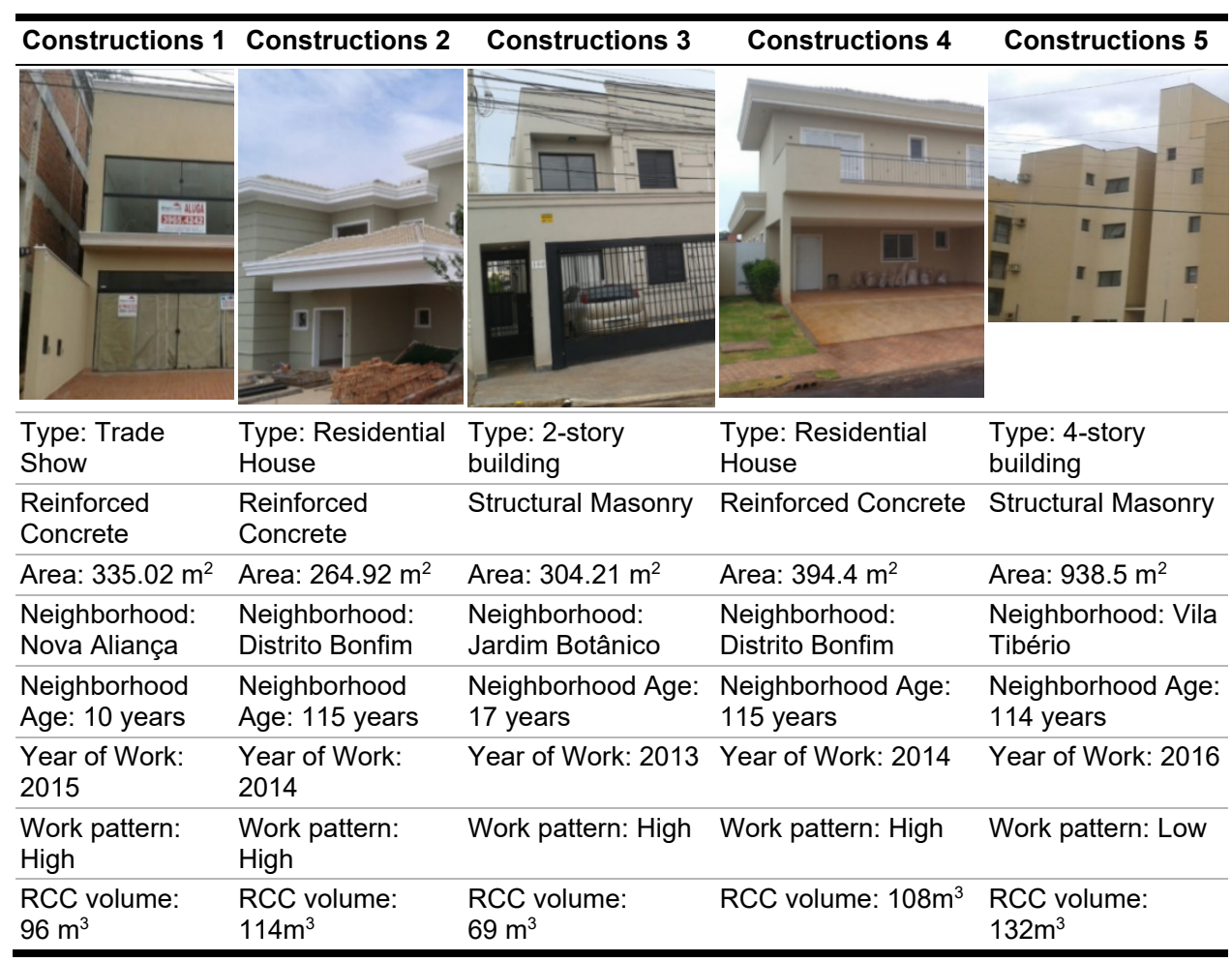

Source: Elaborated by the author (2016).

\subsection{Calculation of RCD generation rate in Ribeirao Preto - SP}

Data:

Bucket capacity: $3 \mathrm{~m}^{3}$

Unit mass: $0.79 \mathrm{t} / \mathrm{m}^{3}$ (Obtained from the qualitative characterization of Ribeirao Preto)

According to Table 5:

Table 5. Calculation of RCD generation rate in Ribeirao Preto-SP.

\begin{tabular}{lcccccc}
\hline \multicolumn{1}{c}{ Works } & $\mathbf{1}$ & $\mathbf{2}$ & $\mathbf{3}$ & $\mathbf{4}$ & $\mathbf{5}$ & Total \\
\hline Area $\left(\mathbf{m}^{\mathbf{2}}\right)$ & 335.02 & 264.92 & 304.21 & 394.4 & 938.5 & $\mathbf{2 , 2 3 7 . 0 5}$ \\
\hline \# Buckets & 32 & 38 & 23 & 36 & 44 & $\mathbf{1 7 3}$ \\
\hline Volume & 96 & 114 & 69 & 108 & 132 & $\mathbf{5 1 9}$ \\
\hline
\end{tabular}

Source: Elaborated by the author (2016)

\subsection{Calculation of RCD generation rate considering $0.79 \mathrm{t} / \mathrm{m}^{3}$}

Rubble mass (Vol. X Unit mass): $519 \mathrm{~m}^{3} \times 0.79 \mathrm{t} / \mathrm{m}^{3}=410.01 \mathrm{t}=410,010.00 \mathrm{~kg}$ RCD Generation Rate (Rubble Mass $/$ Total Area): 410,010/2,237.05 = $183.28 \mathrm{~kg} / \mathrm{m}^{2}$

Ribeirao Preto $-\mathrm{SP}=183.28 \mathrm{~kg} / \mathrm{m}^{2}=0.122 \mathrm{~m}^{3} / \mathrm{m}^{2}$

Marques Neto $(2003)=137.02 \mathrm{~kg} / \mathrm{m}^{2}$ - Sao Carlos $-\mathrm{SP}$ 
Access to documentation of the works, allowed the survey of waste generation during each stage, through the number of buckets generated respectively in the earthmoving, foundation, structures, masonry, coating and finishing phases. With this, it is possible to realize that the stage that generated the most RCD is the masonry and the coating, according to Graph 1. A fact that can be justified by two works that was executed in structural masonry and with this, they presented steps with the largest number of part breaks for their execution.

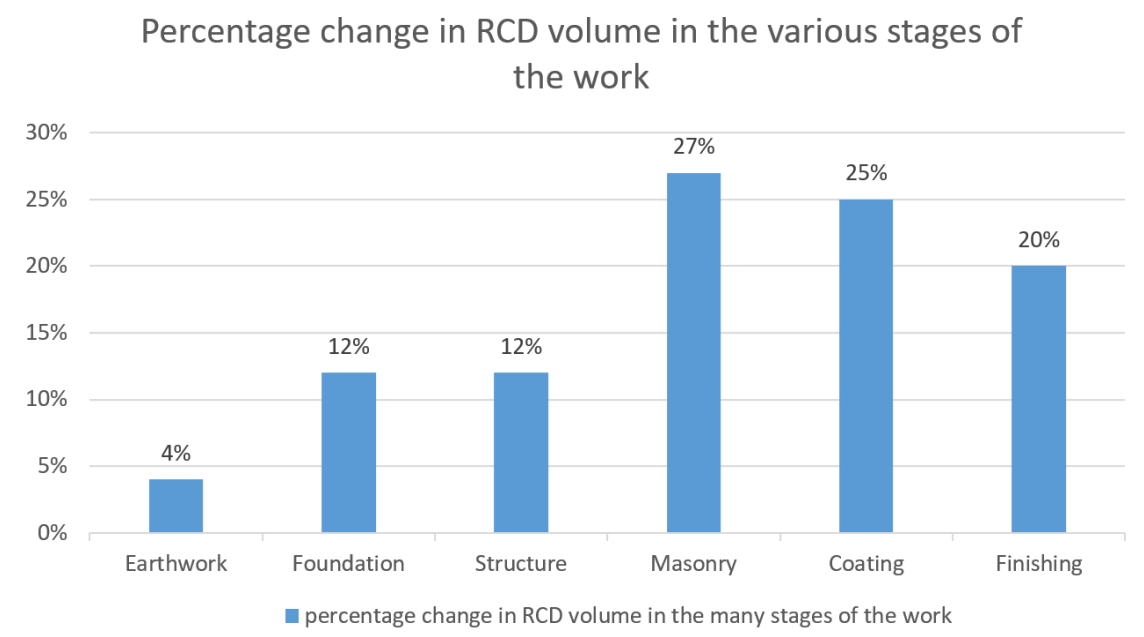

Graph 1. Percentage change in RCD volume. Source: Author (2014).

It is noteworthy that the value found of $183.28 \mathrm{Kg} / \mathrm{m}^{2}$ for the RCD generation rate is considered an estimated value for the city of Ribeirao Preto, since the physical and qualitative analysis of the construction waste performed by the author, considered that the samples were taken randomly from the buckets the way the material arrived, therefore being considered with voids. In this analysis, the value of the unit mass used to calculate the RCD generation rate for the city of Ribeirao Preto was $0.79 \mathrm{t} / \mathrm{m}^{3}$, providing a value below the values found by authors such as Pinto (1999), which found a value of $1.2 \mathrm{t} / \mathrm{m}^{3}$. The unit mass value of $1.2 \mathrm{t} / \mathrm{m}^{3}$ is an important index to be considered for RCD recycling since, as this value is generally used when working with ground RCD samples and not samples taken from the bucket at the moment the final destination, as practiced in this work. With this, the adoption of the found value of $0.79 \mathrm{t} / \mathrm{m}^{3}$ is considered more compatible for works involving the management of construction waste.

\subsection{Quantitative characterization of RCD by parameter of areas licensed for construction in Ribeirao Preto}

For the continuation of the work, a survey was conducted through information from the Ribeirao Preto City hall of the areas licensed and authorized for construction in $2013,2014,2015$ and 2016. It is worth mentioning that the quantitative survey of the licensed areas was calculated by the urban planning sector of the Ribeirao Preto City hall and include the built areas of new works and renovations. Demolition works are 
not being considered, therefore, it seeks compensation for clandestine works in the municipality.

It is possible to notice a decline in the number of built areas from 2013 , with a small recovery in 2016, a fact that can be justified and verified with the decline of the country's economy in the same period. Having verified the variations of the Brazilian PIB in the period of study, we noticed a retraction in the economy, with a resumption from 2016. This fact connects the fall in the number of licensed works, because the activity of construction is directly linked to the economy of the country.

Therefore, Tables 6 and 7 show the quantities of licensed areas in the years 2013, 2014, 2015 and 2016:

Table 6. Licensed Areas in Ribeirao Preto (2013 and 2014).

\begin{tabular}{lrrrr}
\hline \multirow{2}{*}{ Month } & \multicolumn{2}{c}{$\mathbf{2 0 1 3}$} & \multicolumn{2}{c}{$\mathbf{2 0 1 4}$} \\
\cline { 2 - 5 } Jan & 205.00 & Approved $\left.\mathbf{( m}^{\mathbf{2}}\right)$ & Amount & Approved $\left.\mathbf{( m}^{\mathbf{2}}\right)$ \\
\hline Feb & 164.00 & $136,133.02$ & 169.00 & $114,308.18$ \\
\hline Mar & 201.00 & $65,366.37$ & 158.00 & $98,173.54$ \\
\hline Apr & 203.00 & $29,6878.76$ & 218.00 & $133,619.65$ \\
\hline May & 274.00 & $137,752.25$ & 211.00 & $220,316.08$ \\
\hline Jun & 197.00 & $135,283.40$ & 238.00 & $168,640.56$ \\
\hline Jul & 211.00 & $162,277.04$ & 217.00 & $177,724.65$ \\
\hline Aug & 200.00 & $263,551.22$ & 251.00 & $102,933.08$ \\
\hline Sep & 234.00 & $475,740.20$ & 196.00 & $193,779.86$ \\
\hline Oct & 278.00 & $184,535.16$ & 186.00 & $155,515.56$ \\
\hline Nov & 207.00 & $432,058.73$ & 217.00 & $318,011.16$ \\
\hline Dec & 161.00 & $109,653.21$ & 120.00 & $182,578.58$ \\
\hline Total & $\mathbf{2 , 5 3 5 . 0 0}$ & $\mathbf{2 , 5 3 5 , 9 7 4 . 5 9}$ & $\mathbf{2 , 3 6 6 . 0 0}$ & $\mathbf{2 , 0 8 4 , 9 7 7 . 4 3}$ \\
\hline
\end{tabular}

Source: Elaborated by the author (2016).

Table 7. Licensed Areas in Ribeirao Preto (2015 and 2016).

\begin{tabular}{lcrrr}
\hline \multirow{2}{*}{ Month } & \multicolumn{2}{c}{$\mathbf{2 0 1 5}$} & \multicolumn{2}{c}{$\mathbf{2 0 1 6}$} \\
\cline { 2 - 5 } & Amount & Approved $\mathbf{( m}^{\mathbf{2}} \mathbf{n}$ & Amount & Approved $\mathbf{( m}^{\mathbf{2}} \mathbf{~}$ \\
\hline Jan & 164.00 & $245,260.83$ & 160.00 & $148,830.11$ \\
\hline Feb & 195.00 & $100,893.27$ & 124.00 & $58,541.04$ \\
\hline Mar & 629.00 & $141,916.43$ & 195.00 & $108,934.04$ \\
\hline Apr & 203.00 & $160,721.86$ & 117.00 & $94,165.78$ \\
\hline May & 263.00 & $115,748.37$ & 145.00 & $96,015.95$ \\
\hline Jun & 209.00 & $119,279.84$ & 198.00 & $161,123.19$ \\
\hline Jul & 215.00 & $178,129.50$ & 167.00 & $79,007.28$ \\
\hline Aug & 180.00 & $86,397.12$ & 265.00 & $108,139.26$ \\
\hline Sep & 155.00 & $107,022.19$ & 183.00 & $72,818.38$ \\
\hline Oct & 182.00 & $93,149.15$ & 244.00 & $207,919.27$ \\
\hline Nov & 150.00 & $97,989.88$ & 144.00 & $223,975.01$ \\
\hline Dec & 249.00 & $187,523.72$ & 247.00 & $502,325.28$ \\
\hline Total & $\mathbf{2 , 7 9 4 . 0 0}$ & $\mathbf{1 , 6 3 4 , 0 3 2 . 1 4}$ & $\mathbf{2 , 1 8 9 . 0 0}$ & $\mathbf{1 , 8 6 1 , 7 9 4 . 5 7}$ \\
\hline
\end{tabular}

Source: Elaborated by the author (2016). 
Thus, by applying the RCD generation rate to the licensed areas in Ribeirao Preto, the average annual production was obtained. However, for the calculation of RCD generation, only the last 2 years were considered, as it was the duration of the works. Therefore, the average RCD generation was $1,112.35 \mathrm{t} /$ day, or $741.57 \mathrm{~m}^{3} /$ day, according to Table 8:

Table 8. Estimated RCD generation by licensed areas.

\begin{tabular}{lccccc}
\hline & $\mathbf{2 0 1 3}$ & $\mathbf{2 0 1 4}$ & $\mathbf{2 0 1 5}$ & $\mathbf{2 0 1 6}$ & Average \\
\hline Licensed Areas & $2,535,974.59$ & $2,084,977.43$ & $1,634,032.14$ & $1,861,794.57$ & $2,029,194.68$ \\
\hline Generation Rate $\left(\mathbf{k g} / \mathbf{m}^{\mathbf{2}}\right)$ & $\mathbf{1 8 3 . 2 8}$ & 183.28 & 183.28 & 183.28 & 183.28 \\
\hline $\mathbf{R C D}$ generation (t/year) & $464,793.42$ & $382,134.66$ & $299,485.41$ & $341,229.71$ & $371,910.80$ \\
\hline $\mathbf{R C D}$ generation (t/month) & $38,732.79$ & $31,844.56$ & $24,957.12$ & $28,435.81$ & $30,992.57$ \\
\hline $\mathbf{R C D}$ generation (t/day) & $1,613.87$ & $1,326.86$ & $1,039.88$ & $1,184.83$ & $1,291.36$ \\
\hline $\mathbf{R C D}$ generation (m/day) & $1,075.91$ & 884.57 & 693.25 & 789.89 & 860.90 \\
\hline
\end{tabular}

Source: Elaborated by the author (2015).

\subsection{Quantitative characterization of RCD by the parameter of disposals in authorized places.}

This survey was carried out in places authorized by the Ribeirao Preto city hall, characterized by 5 ATTs and 6 RCD plants. Bucket movement was controlled by surveying the amount of buckets received in the 4-month period, September, October, November, and December 2016.

According to Marques Neto (2003) the period of 4 months can be considered significant, as it represents $33.33 \%$ of the year, and it is possible to evaluate the movement of cargo of companies, individuals, and the city itself, as well as their social programs.

Table 9 shows the volumes received from RCD in the 11 construction waste receiving units of the city of Ribeirao Preto in the periods of September, October, November and December 2016. These values were found considering the school days of according to Table 9:

Table 9. RCD received in the months of September/October/November/December 2016.

\begin{tabular}{lccccc}
\hline \multicolumn{1}{c}{ COLLECTOR } & SEP $\left(\mathbf{m}^{\mathbf{3}}\right)$ & OCT $\left(\mathbf{m}^{\mathbf{3}}\right)$ & NOV $\left(\mathbf{m}^{\mathbf{3}}\right)$ & DEC $\left(\mathbf{m}^{\mathbf{3}}\right)$ & TOTAL $\left(\mathbf{m}^{\mathbf{3}}\right)$ \\
\hline ATT-A & 750 & 975 & 936 & 897 & 3,558 \\
\hline ATT-B & 699 & 600 & 666 & 750 & 2,715 \\
\hline ATT-C & 700 & 622 & 430 & 411 & 2,163 \\
\hline ATT-D & 4,620 & 4,290 & 4,950 & 3,960 & 17,820 \\
\hline ATT-E & 792 & 924 & 990 & 726 & 3,432 \\
\hline POWER PLANT -A & 105 & 120 & 75 & 93 & 393 \\
\hline POWER PLANT -B & 1,905 & 2,313 & 2,050 & 749 & 7,017 \\
\hline POWER PLANT -C & 542 & 611 & 520 & 490 & 2,163 \\
\hline POWER PLANT -D & 866 & 954 & 688 & 1,272 & 3,780 \\
\hline POWER PLANT -E & 2,520 & 2,700 & 3,000 & 2,772 & 10,992 \\
\hline POWER PLANT -F & 3,540 & $\mathbf{1 , 2 5 0}$ & - & - & 4,790 \\
\hline TOTAL & $\mathbf{1 7 , 0 3 9 . 0 0}$ & $\mathbf{1 5 , 3 5 9 . 0 0}$ & $\mathbf{1 4 , 3 0 5 . 0 0}$ & $\mathbf{1 2 , 1 2 0 . 0 0}$ & $\mathbf{5 8 , 8 2 3 . 0 0}$ \\
\hline
\end{tabular}

Source: Elaborated by the author (2016). 
During the analysis period, the collecting companies discarded $58,823 \mathrm{~m}^{3}$ of RCD in authorized deposits, about $708,71 \mathrm{~m}^{3} /$ day. Using the unit mass of rubbish of $0.79 \mathrm{t} / \mathrm{m}^{3}, 561.98 \mathrm{t} /$ day were discarded. Comparing the values found with the work of Tessaro et al. (2012) where a RCD generation value was found by the parameter disposed at authorized sites of $315.08 \mathrm{~m}^{3} /$ day for the municipality of Pelotas-RS, which had at the time of the research a population of 328,275 inhabitants. In Ribeirao Preto$\mathrm{SP}$, where the value found was $708.71 \mathrm{~m}^{3} /$ day with a population of 682,302 inhabitants (IBGE, 2017), we can consider that there was a higher production, according to Table 10:

Table 10. RCD Production.

\begin{tabular}{lcccc}
\hline Months & Volume $\left(\mathbf{m}^{3}\right)$ & $\begin{array}{c}\text { Days of } \\
\text { Discard }\end{array}$ & $\begin{array}{c}\text { RCD generation } \\
\left(\mathbf{m}^{3} / \text { day }\right)\end{array}$ & $\begin{array}{c}\text { RCD generation } \\
(\mathbf{t} / \text { day })\end{array}$ \\
\hline September & 17,039 & 21 & 811.38 & 640.99 \\
\hline October & 15,359 & 20 & 767.95 & 606.68 \\
\hline November & 14,305 & 20 & 715.25 & 565.05 \\
\hline December & 12,120 & 22 & 550.91 & 435.22 \\
\hline
\end{tabular}

Source: Elaborated by the author (2016).

\subsection{Likely total RCD generation and per person generation in the municipality}

The parameters presented to determine the generation of RCD in Ribeirao Preto presented varied results. The parameter discarded in authorized places is what best represents the situation of the RCD, as it presents the actual quantities practiced in the municipality. With the parameters licensed area and disposal in authorized locations, it is also possible to verify the magnitude of irregular discharges in the municipality of Ribeirao Preto, because, as verified, the values found in the calculations of licensed areas are greater than the values recorded in the disposal sites. This means that RCD discharges occur in inappropriate places, such as some city avenues and dirt roads that give access to the municipality.

It is important to point out that in the calculation of the licensed areas, the value found already considers the licensed areas and the renovations, as well as, in the parameter discarding volumes in places authorized by the city, the trucks of earthmoving companies, trucks of industries that generate some kind of inert waste.

Thus, the RCD production of Ribeirao Preto, presented in Table 11, shows the generation per person:

Table 11. RCD Generation per person.

\begin{tabular}{lccc}
\hline \multicolumn{1}{c}{ Parameter } & $\begin{array}{c}\text { RCD generation } \\
\text { (t/day) }\end{array}$ & $\begin{array}{c}\text { Population } \\
\mathbf{( 2 0 1 6 )}\end{array}$ & $\begin{array}{c}\text { Generation per } \\
\text { person } \\
\text { (kg/inhab } \times \text { day) }\end{array}$ \\
\hline Licensed Area & $1,112.35$ & 674,405 & 1.65 \\
\hline Authorized Discards & 561.98 & 674,405 & 0.83 \\
\hline Average & $\mathbf{8 3 7 . 1 7}$ & $\mathbf{6 7 4 , 4 0 5}$ & $\mathbf{1 . 2 4}$ \\
\hline
\end{tabular}

Source: Elaborated by the author (2016). 
Per person generation was calculated using data from the population of Ribeirao Preto of 2016, taken from the IBGE census.

In conclusion, compared to the per person generation rate of other municipalities, such as Sao Carlos in 2003, the rate of Ribeirao Preto is low.

Marques Neto (2003) found for the city of Sao Carlos the value of $1.93 \mathrm{~kg} / \mathrm{inhab} \times$ day.

It is noteworthy that the per person generation data found, of $1.24 \mathrm{~kg} / \mathrm{inhab} \mathrm{x}$ days are not $100 \%$ true, given that there may be more areas of un computed clandestine disposal.

One of the major problems faced by the municipality of Ribeirao Preto is the high rate of RCD generation, which is growing and generating serious environmental impacts. Despite CONAMA Resolution No. 307 establishing guidelines for the proper management of waste generated, Ribeirao Preto is far from solving the problem, given the high rates of generation and high rates of irregular disposal in the city, thus the model of integrated construction waste management in Ribeirao Preto is deficient and with several critical points (Brasil, 2002).

In order to minimize the irregular disposal of RCD in the city and function as a kind of Eco Points, the Ribeirao Preto Environment Secretary, together with the Public Cleaning Coordination, created the social bucket program, which consists of placing buckets in many neighborhoods around the city so the population can discard the small volume RCDs. This program has been showing good results, but it has been generating some problems, because in some neighborhoods it is not being accepted by the population.

The government must take responsibility and create policies that favor the supervision of the correct management of RCD produced in the city of Ribeirao Preto, since policies already exist for this purpose.

Another problem considered as one of the main reasons for the high rates of RCD generation is the lack of waste management at construction sites by construction companies. Currently, in Ribeirao Preto, the construction companies do not have a policy that aims to reduce, reuse and recycle the waste generated at the construction sites, resulting in the search for the classic model of final disposal of the RCD, which hires a transport company waste to transport the waste generated at the works to their final destination. These companies are rooted in the culture of the extra costs related to the treatment of the generated RCD, without realizing the medium to long term savings generated.

\section{Conclusion}

The present work, established a quantitative study, outlined the research through a methodology that evaluates the generations of construction waste, using the areas licensed for construction and the quantities disposed of in authorized sites.

In the first parameter (licensed areas) the study begins with the determination of five works started and completed in the last 4 years, thus allowing to calculate the generation rate of the RCD, applying the unit mass value of $0.79 \mathrm{t} / \mathrm{m}^{3}$ found in previous studies by the author and comparing with the value of $0.6 \mathrm{t} / \mathrm{m}^{3}$ as established by Marques Neto (2003), obtaining a value of $183.28 \mathrm{~kg} / \mathrm{m}^{2}$. Then, a survey of the licensed areas was carried out, through information collected by the author in the planning department of the Ribeirao Preto municipal government, allowing to relate the RCD 
generation rate and the licensed areas and obtaining the annual generation rates, monthly and daily rates for each year of the study.

Compared with the literature, it was concluded that the values are considered compatible. This research will be the basis for information for future studies, such as the calculation of waste generation by movement of collecting companies, volume of RCD for landfill disposal and works for the geology area. It was also possible to conclude that most of the RCD generated was in the masonry, coating and finishing stages. This fact can be explained by the study being composed of two works in structural masonry, which contributed to the generation of waste and the fact that the coating and finishing have more cuts, thus increasing the volume of RCD.

In the second parameter of RCD generation presented, it was possible to verify the values discarded in the months of September, October, November and December 2016, obtaining the following values respectively: $17,039 \mathrm{~m}^{3}, 15,359 \mathrm{~m}^{3}, 14,305 \mathrm{~m}^{3}$ and $12,120 \mathrm{~m}^{3}$. With this it was possible to conclude that huge amounts of RCD are being discarded in irregular places, because comparing the values discarded in the authorized landfills with the parameter licensed areas, there is a difference of values. Then, by comparing the licensed area parameter with the disposal parameter in authorized locations, it was possible to calculate the per person generation of the municipality of Ribeirao Preto of $1.24 \mathrm{~kg} / \mathrm{inhab} . \times$ day.

\subsection{Construction waste management model of Ribeirao Preto-SP}

It can be concluded that the model implemented and used by the city of Ribeirao Preto for the integrated management of construction waste has many failures, damaging the system and affecting the agents involved. An example is the lack of infrastructure compared to demand, analyzing the areas licensed for construction and the generation of RCD in the period, it was clear the lack of more scattered sites in the city, facilitating and encouraging the proper disposal of construction waste.

In the same way, programs implemented by the government, such as social buckets, have been generating a certain parallel trade, since people and carts who lives around the social buckets charge residents to discard the RCDs on the site. These facts also create another public health problem, because these people who lives around the social buckets, are looking for valuables and thus expose themselves to diseases and dangerous insects. Thus, it is possible to conclude that the initiatives implemented by the city hall are good, but must be supervised and monitored.

In order to find a solution to the problem presented, new policies for the correct management of construction waste should be regulated, where the following items should be considered:

- Upon approval of the project to regularize the work, present a management plan for the construction waste;

- Fines to agents involved in irregular disposal (generator, carrier and final destination);

- Regulate the use of recycled materials from construction waste in public works of the municipality;

Therefore, the present work theoretically and practically showed the subject of RCD, raised a parameter of the generation rate, thus contributing information for future studies and pointing out the phases of higher RCD generation. 


\section{References}

Abreu, J. N. A. (2016). Base para a gestão de resíduos da construção civil no munícipio de Belo Horizonte (Dissertação de mestrado). Universidade Federal de Santa Catarina, Florianópolis.

Andrade, A. C., Souza, U. E. L., Paliari, J. C., \& Agopyan, V. (2001). Estimativa da quantidade de entulho produzido em obras de construção de edifícios. In Anais do IV Seminário Desenvolvimento Sustentável e a Reciclagem na Construção Civil. São Paulo: Comitê Técnico CT 206.

Ângulo, S. C., \& John, V. M. (2004). Variabilidade dos agregados graúdos de resíduos de construção e demolição recicláveis. Revista de Ciências e Tecnologia de Materiais de Construção Civil, 1(1), 22-32.

Associação Brasileira de Empresas de Limpeza Pública e Resíduos Especiais - ABRELPE. (2011). panorama dos resíduos sólidos no Brasil. Retrieved in 2016, January 20, from www.abrelpe.org.br/

Bidone, F. R. A. (2001). Metodologias e técnicas de minimização, reciclagem e reutilização de resíduos sólidos urbanos. Rio de Janeiro: ABES.

Brasil. (1986, 17 de fevereiro). Resolução CONAMA n 1, de 23 de janeiro de 1986. Dispõe sobre critérios básicos e diretrizes gerais para a avaliação de impacto ambiental. Brasília, DF: Diário Oficial da República Federativa do Brasil.

Brasil. (2002, 17 de julho). Resolução CONAMA n 307, de 5 de julho de 2002. Estabelece diretrizes, critérios e procedimentos para a gestão dos resíduos da construção civil (seção 1, n 136, pp. 95-96). Brasília, DF: Diário Oficial da República Federativa do Brasil.

Buselli, A. A. P. T. (2012). Proposta de gestão dos resíduos de construção e demolição (RCD) no município de Viços (Tese de doutorado). Departamento de Engenharia Civil, Universidade Federal de Viçosa, Viçosa.

Cardoso, A. C. N. (2010). Gestão da qualidade em obras públicas: diretrizes para a gestão de resíduos sólidos da construção civil no canteiro de obras (Monografia). Universidade Federal do Paraná, Curitiba.

Careli, E. D. (2008). CONAMA Resolution No. 307/2002 and the New Conditions for Construction and Demolition Waste Management. 2008 (Dissertation - Master in Civil Engineering). Paula Technological Education State Center Souza, São Paulo, 154 f.

Carneiro, F. P. (2005). Diagnosis and actions of the current situation of waste construction and demolition in the city of Recife. 2005 (Dissertation - Master in Urban Engineering). Federal University of Paraíba, João Pessoa, $131 \mathrm{f}$.

Carneiro, F. P., Brum, I. A. S., \& Cassa, J. C. S. (2001). Reciclagem de entulho para produção de materiais para construção: Projeto Entulho Bom. Salvador: EDUFBA.

Castro, L. O. A. (2003). Destinação dos resíduos de construção e demolição na área insular do município de Santos e seus impactos sanitários e ambientais (Dissertação de mestrado). Faculdade de Saúde Pública, Universidade de São Paulo, São Paulo.

Córdoba, R. E. (2010). Estudo do sistema de gerenciamento integrado de resíduos de construção e demolição do município de São Carlos-SP (Dissertação de mestrado). Escola de Engenharia de São Carlos, Universidade de São Carlos, São Carlos.

Costa, R. G. V. (2012). Taxa de geração de resíduos da construção civil em edificações na cidade de João Pessoa (Dissertação de mestrado). Universidade Federal da Paraíba, João Pessoa.

Dias, J. F. (2004). Avaliação de resíduos da fabricação de telhas cerâmicas para seu emprego em camadas de pavimento de baixo custo (Tese de doutorado). Escola Politécnica, Universidade de São Paulo, São Paulo. 
Dias, M. F. (2013). Modelo para estimar a geração de resíduos na produção de obras residenciais verticais (Dissertação de mestrado). Universidade do Vale do Rio dos Sinos, São Leopoldo.

Formoso, C. T., Jobim, M. S. S., Costa, A. L., \& Rosa, F. P. (1998). Perdas de materiais na construção civil: um estudo em canteiros de obras no Estado do Rio Grande do Sul. In Anais do Congresso Latino Americano de Tecnologia e Gestão na Produção de Edifícios: Soluções para o Terceiro Milênio (Vol. 1, pp. 299-307). São Paulo: EPUSP-PCC.

Freeman, D. (1994). The deconstruction of C\&D waste: nailing down the numbers. World Wastes, 37(6), 36-38.

Instituto Brasileiro de Geografia e Estatística - IBGE. (2017). Brasil: São Paulo: Ribeirão Preto. Retrieved in 2016, November 20, from http://www.cidades.ibge.gov.br/xtras/perfil.php?lang=\&codmun=354340

John, V. M. (2000). Reciclagem de resíduos na construção civil: contribuição para metodologia de pesquisa e desenvolvimento (Tese de livre-docência). Escola Politécnica, Universidade de São Paulo, São Paulo.

John, V. M. (2001). Aproveitamento de resíduos sólidos como materiais de construção. In F. P. Carneiro, I. A. S. Brum \& J. C. S. Cassa (Eds.), Reciclagem de entulho para produção de materiais para construção: Projeto Entulho Bom. Salvador: EDUFBA.

Li, Y., \& Zhang, X. (2013). Web-based construction waste estimation sys-tem for building construction projects. Automation in Construction, 35, 142-156. http://dx.doi.org/10.1016/j.autcon.2013.05.002.

Lu, W., Webster, C., Peng, Y., Chen, X., \& Zhang, X. (2017). Estimating the amount of buildingrelated construction and demolition waste in China. International Journal of Construction Management, 17(1), 13-24. http://dx.doi.org/10.1080/15623599.2016.1166548.

Lúcio, R. F. (2013). Diagnóstico do sistema de gerenciamento de resíduos de construção e demolição no município de Belo Horizonte - MG (Dissertação de mestrado). Escola de Engenharia. Universidade Federal de Minas Gerais, Belo Horizonte.

Make in India. (2016). Construction statistics on construction sector. Retrieved in 2016, September 20, from http://www.makeinindia.com/sector/construction

Mália, M., Brito, J., Pinheiro, M. D., \& Bravo, M. (2013). Construction and demolition waste indicators. Waste Management \& Research, 31(3), 241-255. http://dx.doi.org/10.1177/0734242X12471707. PMid:23315370.

Mann, D. C. A., Biju, B. P., \& Nagalli, A. (2014). Investigation of potencial areas for installation of C\&D waste landfills in the metropolitan region of Curitiba, Brazil. In ISWA2014 Solid Waste World Congress. Vienna: International Solid Waste Association.

Marques Neto, J. C. (2003). Diagnóstico para estudo de Gestão de Resíduos de Construção e Demolição do Município de São Carlos - SP (Dissertação de mestrado). Escola de Engenharia de São Carlos, Universidade de São Paulo, São Paulo.

Marques Neto, J. C. (2009). Estudo da gestão municipal dos resíduos de construção e demolição na bacia hidrográfica do Turvo Grande (UGRHI-15) (Tese de doutorado). Escola de Engenharia de São Carlos, Universidade de São Paulo.

Mello, E. D., \& Monteiro, J. A. P. (2007). Gestão de resíduos da construção civil. Ribeirão Preto: Painel, AEAARP.

Monteiro, J. H. P., Figueiredo, C. E. M., Magalhães, A. F., Melo, M. A. F., Brito, J. C. X., Almeida, T. P. F., \& Mansur, G. L. (2001). Management Manual, integrated solid waste. Rio de Janeiro: IBAM.

Pinto, T. P. (1999). Metodologia para a gestão diferenciada de resíduos sólidos da construção urbana (Tese de doutorado). Escola Politécnica, Universidade de São Paulo, São Paulo.

Pinto, T. P., \& González, J. L. R. (Eds.), (2005). Manejo e gestão de resíduos da construção civil (Vol. 1, Manual de orientação). Brasília: Caixa Econômica Federal. 
Solís-Guzman, J., Marrero, M., Montes-Delgado, M. V., \& Ramírez-De-Arellano, A. (2009). Spanish model for quantification and management of construction waste. Waste Management (New York, N.Y.), 29(9), 2542-2548. http://dx.doi.org/10.1016/j.wasman.2009.05.009. PMid:19523801.

Tessaro, A. B., De Sá, J. S., \& Scremin, L. B. (2012). Quantification and classification of waste from civil construction and demolition in the municipality of Pelotas, RS. Article. Porto Alegre: Federal University of Rio Grande do Sul. Built Environment, 12(2), 121-130.

Tozzi, R. F. (2006). Estudo da Influência do Gerenciamento na Geração dos Resíduos da Construção Civil (RCC): estudo de Caso de duas obras em Curitiba/PR. Curitiba.

Villoria Sáez, P., del Río Merino, M., \& Porras-Amores, C. (2012). Estimation of construction and demolition waste volume generation in new residential buildings in Spain. Waste Management \& Research, 30(2), 137-146. http://dx.doi.org/10.1177/0734242X11423955. PMid:22081383. 